\title{
A Review of Pharmacognostical Studies on Moringa oleifera Lam. flowers
}

\author{
Tom Mathew Kalappurayil*, Benny Pulinilkkumthadathil Joseph
}

\section{Tom Mathew Kalappuray- il*, Benny Pulinilkkumtha- dathil Joseph}

Department of Zoology, St Thomas College, Pala PIN 686574, Kottayam district, Kerala, INDIA.

\section{Correspondence}

Tom Mathew Kalappurayil*, Research Scholar, Department of Zoology, St Thomas College, Pala PIN 686574 Kottayam district, Kerala, INDIA.

Phone no: 9947851008

E-mail: tom.kmathew@yahoo.com History

- Submission Date: 08-07-2016;

- Review completed: 28-8-2016;

- Accepted Date: 01-09-2016.

DOI : 10.5530/pj.2017.1.1

Article Available online http://www.phcogj.com/v9/i1

\section{Copyright}

(C) 2016 Phcog.Net. This is an openaccess article distributed under the terms of the Creative Commons Attribution 4.0 International license.

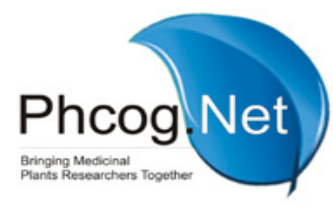

\begin{abstract}
Moringa oleifera Lam. of the family Moringaceae, popularly called 'miracle tree' is a native of sub Himalayan tracts of Northern India and is widely cultivated in tropical and subtropical regions. Research on Moringa mainly pivoted around its leaves and seeds because of their immense nutraceutical potential but recently there is a greater interest in flowers too, mostly inspired by the positive outcomes of several pharmacognostical studies on flowers. Moringa flower is a rich reservoir of bioactive phytochemicals and crude flower extracts showed promising antibacterial, antifungal, anti larval, antioxidant, anti inflammatory and anticancer properties. This review concisely presents the various phytochemicals identified and isolated as well as the various bioassays employed to validate the therapeutic potential of flower. It is prepared after a detailed search on Google scholar. Reports on Moringa oleifera flower were sorted and tabulated based on the bioassays performed and solvents used for extraction. A grading pattern is adopted for comparing efficiency of different extracts in eliciting bioactivities. Many of these studies are at the preliminary stage but two of them present advanced mechanisms. First is the presence of a proteinaceous larvicidal compound ' $\mathrm{MoFTI}$ in the flower capable of inhibiting larval trypsin of Aedes aegypti. The second describes flower extract's anti inflammatory mechanism effecting via NF-KB pathway and consequent suppression of inflammatory mediators' activation, but short of identifying lead compound/compounds behind this effect. Thus authors suggest further studies to elucidate the detailed mechanisms, identify and isolate the active compound or compounds of synergism behind the many therapeutic potential of the Moringa flower extracts.
\end{abstract}

Key words: Extracts, Moringa, Flower, Bioactivity, Phytochemicals, GCMS, Bioassay, Therapeutic.

\section{INTRODUCTION}

Pharmocognostical studies on Moringa oleifera LAM. has begun as early in 1950s which led to the discovery of antibacterial pterygospermin in the plant. ${ }^{1}$ Recent research helped to validate many of $M$. oleifera's traditional claims such as antibacterial and antitumor properties. For instance, Jed W Fahey (2005) refers to two molecules from this plant, 4-(-L-rhamnopyranosyloxy) benzyl isothiocyanate and Niazimicin of being active against Helicobacterium pylori and tumor growth respectively, but recommends rigorous research of international standard essential before moving to full biomedical endorsement of $M$. oelifera. Hitherto such investigations mainly concentrated on leaves due to its proven potential as an exceptional nutraceutical. ${ }^{2}$ On other hand Moringa flowers received little attention of researchers in spite of its significant nutritional and traditional healing properties. ' 'Muringa Poovu thoran' is a tasty and a seasonal dish of Malayalees made from Moringa flowers. In other parts of world too, flowers are favorite ingredients of various dishes such as lasagna, omelet, soups, sea foods, pasta dishes, pizza pakoras etc or eaten raw as salads, or used for making tea and honey. ${ }^{4}$ Bhavaprakasa of Bhava Misra, an important treatise on Ayurveda depicts Shigru flowers (Moringa flowers) as Drusti Pathya meaning wholesome food for eyes. ${ }^{5}$ Anwar et al made a concise presentation of common medicinal uses of different parts of Moringa oleifera with an impressive list assigned to flower alone that include its high medicinal value as a stimulant, aphrodisiac, abortifacient and cholagogue. This study starts with a short description on morphology and anatomy of the flowers, major phytochemicals present, and compounds identified and isolated. Bioassays of flowers conducted in different extracts are then presented in a tabular form so as to make an easy assessment on the pharmacognostical prospects of the flower.

Review was prepared based on a detailed search on google scholar for Moringa oleifera related reports. Reports were sorted based on the bioassays performed. Those activities are tabulated against solvents used in the extraction of phytochemicals from flowers. A grading pattern is adopted for comparing efficiency of these extracts in eliciting bioactivities. Abbreviations

Cite this article: Kalappurayil TM, Joseph BP. A Review of Pharmacognostical Studies on Moringa oleifera Lam. flowers. Pharmacognosy Journal. 2017;9(1):1-7. 
$\mathrm{H}, \mathrm{M}, \mathrm{L}$ and $\mathrm{N}$ were used for noting the High, Medium, Low and Nil activity of extracts. These comparisons are true on results obtained from a single assay, but not necessarily between different assays. Nevertheless they are helpful in understanding the efficiency of solvents in eliciting a particular bioactivity.

\section{THE MORINGA FLOWER Morphology and anatomy}

Flowers are fragrant yellowish white, bisexual born in 10 to $25 \mathrm{~cm}$ long axillary, compound inflorescence called panicles. Individual flowers slightly zygomorphic have dimensions of about $1 \mathrm{~cm}$ length by $2 \mathrm{~cm}$ breadth set in a basal cup of thalamus namely hypanthium. Sepals and petals are five in numbers, free, unequal, reflexed and spathulate. Stamens five, dorsifixed filaments of different lengths with posterior ones longest with yellow one celled anthers bending downwards There are five staminodes alternating with the stamens forming an outer whorl. The gynoecium is tricarpellary syncarpous borne on a small gynophore. The ovary continues into a long style which protrude out of anthers and end in creamy white and pitted stigma. Reports suggest a pollen presentation mechanism for behind the overall logistics ${ }^{6-9}$ There are two peaks of flowering October-November rainy season and April-May summer season. ${ }^{10}$

\section{Phytochemistry}

Proximate analysis found that percentage of dry weight of proteins in flowers is 18.92 , ash 9.68, lipids 2.91 , dietary fibre 32.45 and non structural carbohydrate 36.04 which suggest a comparable nutritional profile for leaves and flowers. ${ }^{11}$ Total Antioxidant Content of flower is also found higher than other plant parts. ${ }^{12}$ Flower contains all the 20 amino acids and the percentage of essential to nonessential amino acids is almost equal. ${ }^{13}$ The vitamin $\mathrm{C}$ content in flowers was found to be in highest 77.502 to $224.672 \mathrm{mg} / 100 \mathrm{~g}$ when compared to other parts. ${ }^{14}$ A number of qualitative analysis of various flower extracts confirmed the presence of saponins, tannins, alkaloids, flavonoids, steroids, glycosides, terpenoids and phenols etc though there are some slight differences in reports, most probably arising out of protocols followed for sample preparation and extraction. ${ }^{15-21}$ Most of them air dried fresh flowers, powdered and macerated with occasional soxhlation and employed distilled water, methanol, acetone, ethyl acetate, chloroform or hexane etc for extraction. The yield for various solvents is found to be in the order of Aqueous> Methanol $>$ Ethanol $>$ Acetone $>$ Ethyl acetate $>$ Hexane. Preferred solvent is methanol as it found to contain the most bioactive fractions. Generally the phytochemical composition depends on the geographical location and age of the plant and extraction protocols. ${ }^{3}$

\section{Major compounds identified}

Modern analytical tools were employed to profile the phytochemical composition of Moringa flowers. Gas Chromatography Mass spectrometry (GCMS) done on methanol extract of flowers identified 26 compounds in which ethyl oleate, quinic acid and cis -9- hexadecenal are the major constituents with reported anticancer, anti inflammatory, antioxidant properties. ${ }^{22}$ Simultaneous distillation-extraction and capillary gas chromatography/mass spectrometry of flower volatile compounds identified Seventy-four molecules in which the major compounds are (E)-nerolidol (13.33\%) a-terpineol (7.8\%) and benzyl isothiocyanate $(6.4 \%) .{ }^{23}$ When freeze-dried samples were used for extraction and analysis by HPLC-DAD-electrospray mass spectrometry showed presence of 22 compounds that include Glucosinolates such as benzyl glucosinolate, 4-hydroxybenzyl glucosinolate, 4-O-(a-L-rhamnopyranosyloxy)-benzyl glucosinolate, 4-O-(a-L-acetyl rhamnopyranosyloxy)-benzyl glucosinolate; phenolics such as 5-Caffeoylquinic acid, 3-Caffeoylquinic acid; flavonoids such as Quercetin 3-O-rutinoside, Quercetin 3-O-glucoside, Quercetin 3-O-(6"-malonyl glucoside) Kaempferol 3-O-glucoside, Kaempferol
3-O-rutinoside, Kaempferol 3-O-(6"-malonyl glucoside) and Isorhamnetin 3-O-(6-malonyl glucoside). ${ }^{24}$ When hydroethanolic crude flower extracts is subjected to HPLC- DAD-ESI MS/MS analysis the list of tentative compounds include Quinic acid, 4-p coumaryolquinic acid, Quercetin 3 O acetyl glucoside, Kaempferol-3-O acetyl hexoside, Octadecenoic acid, Heneicosanoic acid, Behenic ( docosanoic) acid. ${ }^{25}$ Presence of a proteinaceous Trypsin inhibitor or MoFTI in aqueous flower preparations was reported. ${ }^{21}$ Backed by this impressive biochemical profile, attempts begin to isolate purify and characterize these compounds but so far the list include only a few -rhamnetin 3-O-(2 " galloyl)- $\beta$-D-galactopyranosyl-4 $-\beta$-D-xylopyranoside, ${ }^{26}$ Kaempferol-7O- $\beta$-D-alloside, ${ }^{27}$ quercetin 3-O- $\alpha$-L rhamnosyl $(1 \rightarrow 6) \beta$ D-glucoside, ${ }^{28}$ and a proteinaceous MoFTI ${ }^{29}$ On the other hand crude flower extracts has been put into all sort of pharmacognostical studies with several promising outcomes in the way. The scope of such studies can be easily accessed from the Table 1.

\section{Pharmacognostical studies}

Most of pharmacognostical studies on Moringa flowers are reported recently. These studies are summarized in the Table 1 in which bioassays performed, solvent extracts employed, results obtained and significance of each study are shown. To compare the efficiency of extract in eliciting a particular bioactivity, four abbreviations ' $\mathrm{H}$ ', ' $\mathrm{M}$ ', 'L' and ' $\mathrm{N}$ ' are used where $\mathrm{H}$ stands for high activity, $\mathrm{M}$ for medium, $\mathrm{L}$ for low and $\mathrm{N}$ for nil activity. The numbers accompanying each of this letters denote the corresponding reference.

\section{DISCUSSSION}

It is evident that Moringa flower is under extensive phytochemical and pharmacological studies for the last couple of years. There are several studies supporting the therapeutic potential of moringa flower. They employed different extracts and covered diverse assays such as antibacterial, antifungal, anti protozoan, larvicidal, antioxidant, anti inflammatory, hepatoprotective, anticancer, osteo protective, uterotonic, antisickling, biofortification, bioremediation and nanoparticle synthesising properties. To make comparison of solvent efficiency easier, abbreviations $\mathrm{H}, \mathrm{M} \mathrm{L}$ and $\mathrm{N}$ were used, corresponding to the high, medium, low and nil activities. Within a report these comparisons are true and indicate their relative efficiency but not necessarily for different reports. Antibacterial studies against of 15 species by either disc or agar well diffusion found methanol and ethanol extracts producing high inhibition zones. Dichloromethane a non polar solvent is also reported to possess antibacterial activity. Antifungal properties were reported for chloroform extracts while ethyl acetate extract is active against protozoan Leishmania donovani. Mosquito larvicidal activity of flower extract is studied elaborately and a proteinaceous Trypsin inhibitor Factor isolated from flower is held responsible for the property. Interestingly larvicidal effect is noted for methanol and ethyl acetate extract too. There are several notable studies on the antioxidant properties of aqueous, methanol, ethanol and acetone extracts of flower. Antioxidant assays such as DPPH, FRAP and TEAC proved that flower has highest total antioxidant content than other plant parts. Though anti inflammatory studies were few, positive results were observed for several parameters such as activation of anti inflammatory mediators and suppression of pro inflammatory mediators. Hepato protective nature of flower extract is essentially an extension of its anti inflammatory and antioxidant potential and they produced good results in vivo with mice models. Bone protective potential of the methanol and ethanol extracts tested osteoblast stimulating potential and overall effect is promising. Uterotonic and anti sickling potential of flower yielded positive results Non-traditional application of flower extracts especially in dairying, bioremediation, biofortification and nanoparticle synthesis 


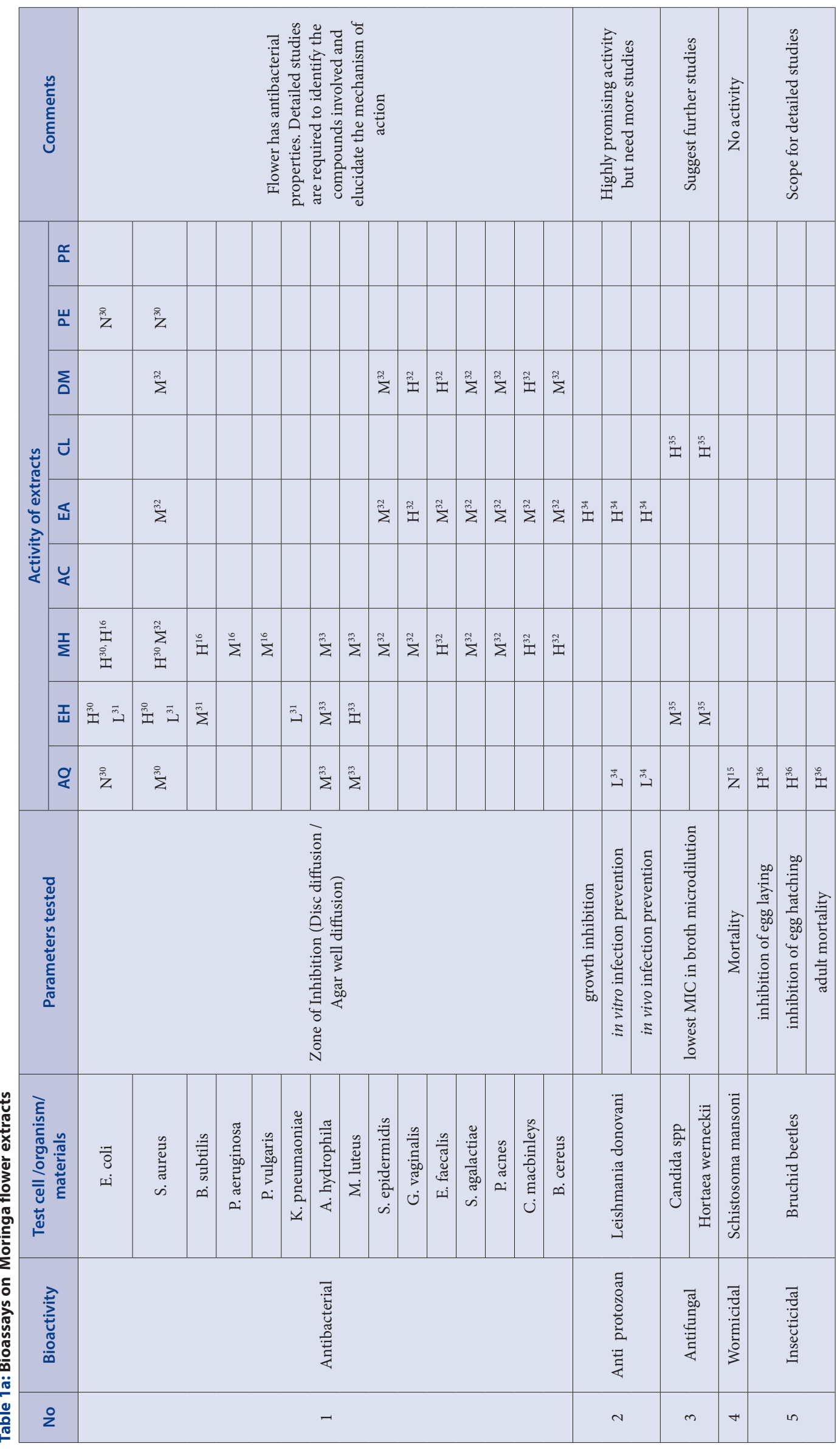




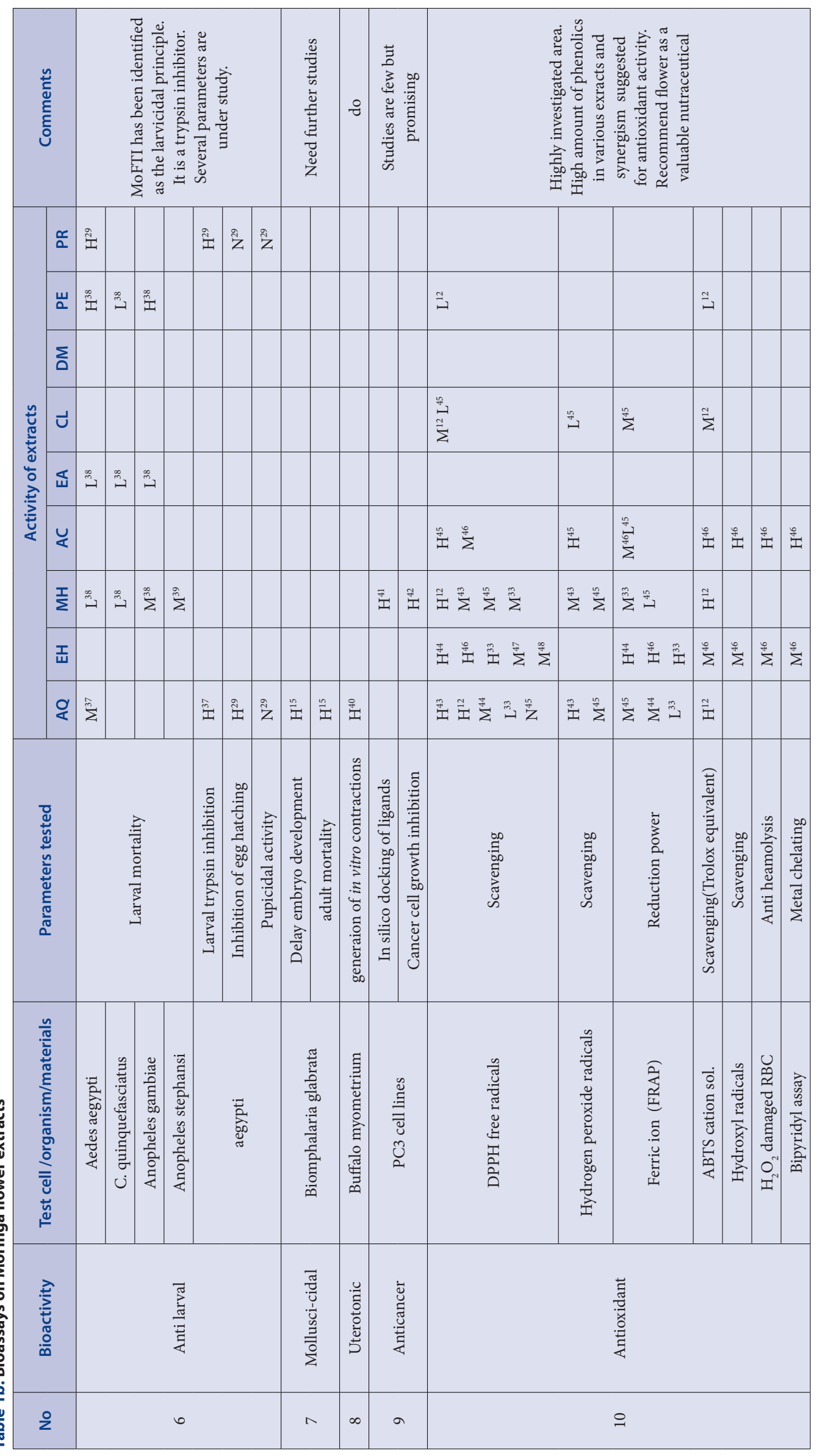




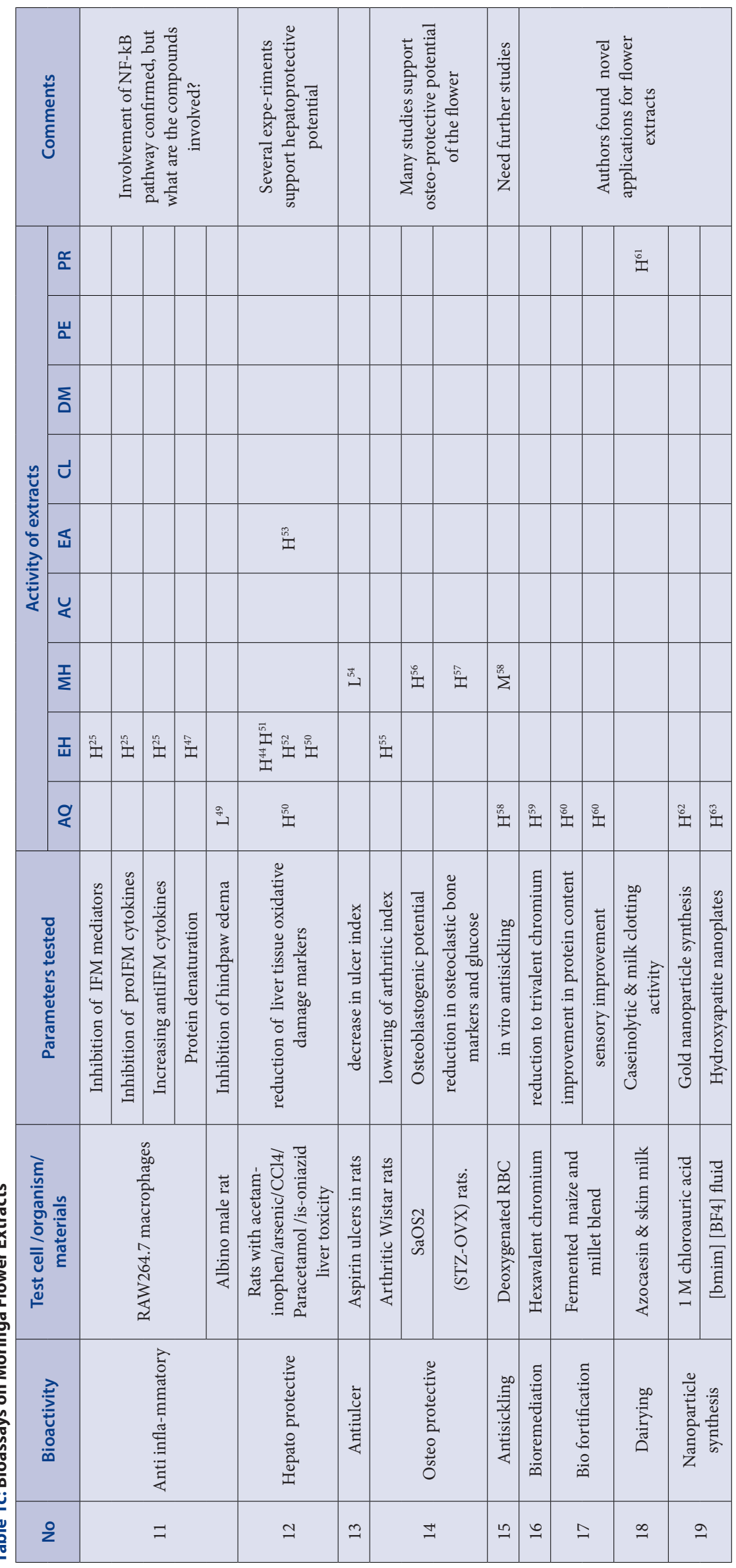


were also attempted successfully. But we need more studies to arrive at a general conclusion on any such properties of the flower.

Table 1 shows that majority of the studies especially antimicrobial, antioxidant, anti inflammatory assays came up with awesome results indicating the huge therapeutic potential $M$. oleifera flower, but these studies still remain in the preliminary stage of investigations. It is can be conclusively said that most of the biologically active secondary metabolites responsible for above said properties can be extracted with polar solvents such as methanol ethanol or acetone. Though there are slight discrepancies between reports on the potentiality of different extracts, it may be due to unavoidable variations in protocol followed for sample collection and preparation. There is huge gap in the number of biologically active phytochemicals identified v/s isolated. In fact all reports suggest further investigations to elaborate up on the bioactivity of the extracts as well as to identify any 'ace compound' in them. Consider the antioxidant, antiinflammatory and hepatoprotective studies in which the same extract give positive results for several related assays. A detailed study well done on the anti inflammatory potential of ethanol extract demonstrates multiple actions such as the Inhibition of NO and pro inflammatory interleukins ( IL- 6 , IL-1 $\beta$, TNF- $\alpha$, and PGE2) and at the same time helping formation of anti inflammatory IL-10 and I $\mathrm{KB}-\alpha$ expressions-all these acting in unison to ameliorate inflammatory damage via NF-kB pathway in macrophages. Here the authors are yet to specify any compound for this pharmocological effect. In the anticancer study, in silico investigation predicted ligand binding of several compounds such as Quinic acid, alpha-Tocopherol-beta-D-mannoside, (4-Hydroxyphenyl) acetonitrile, Ethyl Oleatemade from GC MS analysis of methanol flower extract, more effectively to different drug targets than control drugs in PC3 cell lines. Incorporating such novel assays will lend more light on the specific action of novel phytochemicals. Similarly their synergism in effecting a desirable outcome is also a good possibility and the probable reason behind many of the traditional therapeutic uses. Elucidating these synergistic pathways or tracing the ace compound is a huge challenge for researchers but worth the time and energy as it will lay a strong foundation for evidence based application of traditional medicine systems and development of numerous potential plant extracts into novel drugs.

\section{CONCLUSION}

Flowers of Moringa oleifera, hitherto unexplored part of otherwise hugely investigated Moringa oleifera plant is a storehouse of valuable bioactive phytochemicals. Preliminary investigations into the antibacterial, antifungal, antiviral, antioxidant anti inflammatory and anticancer investigations of various solvent extracts are highly promising. There is scope for detailed studies to elucidate the mechanism behind this high therapeutic potential of Moringa flower as well as to isolate purify and characterize the bioactive phytochemicals.

\section{ACKNOWLEDGEMENT}

None.

\section{CONFLICT OF INTEREST}

The author have no conflict of interest.

\section{ABBREVIATIONS USED}

AQ: Aqueous; EH: Ethanol; MH: Methanol; AC: Acetone; EA: Ethyl acetate; CL: Chloroform; DM: Dichloromethane; PE: Petroleum ether; PR: Protein; H: Activity high; M: Medium; L: Low; N-nil: Blank cells-No reports found.

\section{REFERENCES}

1. Das BR, Kurup PA, Narasimha Rao PL. Antibiotic principle from Moringa pterygosperma. Naturwissenschaften. 1954;1;41(3):66-6.

2. Fahey JW. Moringa oleifera: A Review of the Medical Evidence for Its Nutritional, Therapeutic, and Prophylactic Properties. Part 1. Trees for Life Journal. 2005; 1; 1(5):1-15.

3. Inbathamizh L, Padmini E. Effect of geographical properties on the phytochemical composition and antioxidant potential of Moringa oleifera flowers. Bio Med Rx. 2013;1(3):239-47.

4. Koul B, Chase N. Moringa oleifera Lam.: Panacea to several maladies. JCPRCS. 2015;7(6):687-707.

5. Shubhashree M, Shantha T, Ramarao V, Reddy MP, Venkateshwaraul G. A review on the therapeutic uses of flowers as depicted in classical texts of Ayurveda and Sidha. J Res Educ Indian Med. 2015; 21:1-14. Available from www.scopemed.org/fulltextpdf.php?mno=42055

6. Parrota JA. Moringa oleifera LAM., 1785. In: A. Roloff H. Weisgerber U. Lang and B. Stimm, Editors. Enzyklopadie der Holozgewachse, Hanbuch und Atlas der Dendrologie. Wiley - Vch Verlag GmbH \& Co. KGA, Weinheim, p. 1-9; 2009.

7. Decraene LR, De Laet J, Smets EF. Floral Development and Anatomy of Moringa oleifera (Moringaceae): What is the Evidence for a Capparalean or Sapindalean Affinity?. Annals of Botany. 1998;82(3):273-84. http://dx.doi. org/10.1006/anbo.1998.0677.

8. Puri V. Floral anatomy of the Moringaceae with special reference to gynoecium constitution. Proceedings of the National Institute of Sciences of India Studies in Floral anatomy II; National Institute of Sciences of India; 1942.

9. Muhl QE, duToit ES, Steyn JM, Apostolides Z. Bud development, flowering and fruit set of Moringa oleifera Lam. (Horseradish Tree) as affected by various irrigation levels. JARTS. 2014;114(2):79-87.

10. Kanthaswamy V. Studies on pollination and breeding behaviour in moringa (Moringa oleifera Lam). Vegetable Science. 2005;32(2):187-8.

11. Sánchez-Machado DI, Nú-ez-Gastélum JA, Reyes-Moreno C, Ramírez-Wong B, López-Cervantes J. Nutritional quality of edible parts of Moringa oleifera. Food Anal Methods. 2010;3(3):175-80. http://dx.doi.org/10.1007/s12161-009-9106-z.

12. Vyas $S$, Kothari SKS. Comparative analysis of phenolic contents and total antioxidant capacity of Moringa oleifera Lam. Phcog J. 2015;7(1):44-51. http://dx.doi. org/10.5530/pj.2015.7.5

13. Igwilo 1O, Ezeonu FC, Udedi SC, Ozumba NA. Comparative Studies on the Amino Acid Content of different parts of Moringa oleifera plant found in Awka, South-East, Nigeria. BCAIJ. 2011;5(2):124-7.

14. Ahmed KS, Banik R, Hossain MH, Jahan IA. Vitamin C (L-ascorbic Acid) Content in Different Parts of Moringa oleifera Grown in Bangladesh. ACSJ. 2015:9:11(1):16 .

15. Rocha-Filho CA, Albuquerque LP, Silva LR, Silva PC, Coelho LC, Navarro DM, et al. Assessment of toxicity of Moringa oleifera flower extract to Biomphalaria glabrata, Schistosoma mansoni and Artemia salina. Chemosphere. 2015;132:18892. http://dx.doi.org/10.1016/j.chemosphere.2015.03.041; PMid:25867917.

16. Sumathy $R$, Vijalakshmi M, Deecaraman M, Sankaranarayanan S, Bama $P_{1}$ Ramachandran J. Screening of secondary metabolites antioxidant and antimicrobial activity from the petals of Moringa oleifera. WJPPS. 2014;3(6):1829-43.

17. Sundari UT, Rekha S, Parvathi A. Phytochemical analysis of some therapeutic medicinal flowers. IJOP. 2012:2(3):583-5.

18. Sankhalkar S, Vernekar V. Quantitative and Qualitative analysis of Phenolic and Flavonoid content in Moringa oleifera Lam and Ocimum tenuiflorum L. Pharmacognosy Res. 2016;8(1):16. http://dx.doi.org/10.4103/0974-8490.171095; PMid:26941531 PMCid:PMC4753755

19. Kheir SM, Kafi SK, Elbir H. The antimicrobial activity and phytochemical characteristice of Moringa oleifera seeds, leaves and flowers. WJPR. 2014.3;4(1):258-71.

20. Bargah RK. Preliminary test of phytochemical screening of crude ethanolic and aqueous extract of Moringa pterygosperma Gaertn. JPP. 2015;1;4(1):7-9.

21. Moura MC, Pontual EV, Gomes FS, Napoleão TH, Xavier HS, Paiva PM et al. Preparations of Moringa oleifera flowers to treat contaminated water. In: Justin A. Daniels, Editor. Advances in Envinronmental research Vol 21. Nova Science Publishers. 2011;21:269-85

22. Inbathamizh L, Padmini E. Gas Chromatography-Mass Spectrometric analyses of methanol extract of Moringa oleifera flowers. IJCAS. 2012;3(5):1394-7.

23. Pino JA. Floral Scent Composition of Moringa oleifera Lam. J Essent Oil Bearing Plants. 2013;1;16(3):315-7.

24. Amaglo NK, Bennett RN, Curto RB, Rosa EA, Turco VL, Giuffrida A, et al. Profiling selected phytochemicals and nutrients in different tissues of the multipurpose tree Moringa oleifera L., grown in Ghana. Food Chemistry. 2010;15;122(4):1047-54.

25. Tan WS, Arulselvan P, Karthivashan G, Sharida F. Moringa oleifera flower extract suppresses the activation of inflammatory mediators in lipopolysaccharidestimulated RAW264. 7 macrophages via NF-kB pathway. Mediators of Inflamm. 2015. http://dx.doi.org/10.1155/2015/720171.

26. Bargah RK, Das C. A New flavonol glycoside from the flowers of Moringa ptery gosperma. IOSR-JAC. 2012;3(1):1-3. http://dx.doi.org/10.9790/5736-0310103. 
27. Bargah RK, Das C. Kaempferol-7-O- $\beta$-alloside from Moringa pterygosperma. Oriental Journal of Chemistry. 2008;24(2):771-2

28. Bargah RK, Das C. Isolation of flavonoid glycoside from Moringa pterygosperma. Oriental Journal of Chemistry. 2010;26(3):1203-5

29. Pontual EV, de Lima Santos ND, de Moura MC, Coelho LC, Navarro DM, Napoleão TH, et al. Trypsin inhibitor from Moringa oleifera flowers interferes with survival and development of Aedes aegypti larvae and kills bacteria inhabitant of larvae midgut. Parasitology Research. 2014;113(2):727-33. http://dx.doi. org/10.1007/s00436-013-3702-y; PMid:24271154.

30. Dodiya B. Amin B. Antibacterial Activity and Phytochemical Screening of Different Parts of Moringa oleifera Against Selected Gram Positive and Gram Negative Bacteria. JPCBS. 2015;3(3):421-5.

31. Talreja T. Screening of crude extract of flavonoids of Moringa oleifera against bacteria and fungal pathogen. J Phytol. 2010;2(11).

32. Sumitha J, Padmalatha C, Singh AR. Antibacterial Efficacy of Moringa oleifera and Tabernaemontana divaricata Flower Extracts on Occular Pathogens. Int J Curr Microbiol App Sci. 2015;4(5):203-16

33. Tekle EW, Sahu NP, Makesh M. 1637.Antioxidative and antimicrobial activities of different solvent extracts of Moringa oleifera: an in vitro evaluation. IJSRP. 2015;5(5):1.

34. Singh MK, Paul J, DeT, Chakraborti T. Bioactivity guided fractionation of Moringa oleifera Lam. flower targeting Leishmania donovani. IJEB. 2015;53:747-52.

35. Rocha MF, de Alencar LP, Brilhante RS, de Alencar Sales J, de Ponte YB, de Aragão Rodrigues $\mathrm{PH}$, et al. Moringa oleifera inhibits growth of Candida spp. and Hortaea werneckii isolated from Macrobrachium amazonicum prawn farming with a wide margin of safety. Ciência Rural. 2014;44(12):2197-203. http:// dx.doi.org/10.1590/0103-8478cr20140266.

36. Adenekan MO, Okpeze VE, Ogundipe WF, Oguntade MI. Evaluation of Mor inga oleifera powders for the control of bruchid beetles during storage. IJAPR. 2013;1(10):305-10.

37. Pontual EV, Napoleão TH, Dias de Assis CR, de Souza Bezerra R et al. Effect of Moringa oleifera flower extract on larval trypsin and acethylcholinesterase activities in Aedes aegypti. Archives of Insect Biochemistry and Physiology. 2012;79(3):135-52. http://dx.doi.org/10.1002/arch.21012; PMid:22392801.

38. Nkya JW, Erasto P, Chacha M. Larvicidal against mosquito vectors and brine shrimp activities of extracts from the flowers of Moringa oleifera Lam. Amer J Res Comm. 2014;2(8):15-29.

39. Prasad A, Sharma E. Phytotoxicological assessment of Moringa oleifera Lam. against larvae of important human malaria vector Anopheles stephensi Liston (Insecta: Diptera: Culicidae). IJIAS. 2014;7(4):1633.

40. Singh D, Choudhury S, Singh TU, Garg SK. Pharmacodynamics of uterotonic effect of Moringa oleifera flowers extract. J Veter Pharmacol Toxicol. 2008:7(1 2):12-5.

41. Inbathamizh $L$, Padmini E. Moringa oleifera flower compounds as potent ligands to drug targets in PC3 cell lines-An in silico analysis. Int J Pharm Pharm Sc. 2013;5(4):377-83

42. Inbathamizh L, Padmini E. Evaluation of Growth inhibitory potential of Moringa oleifera flowers on PC3 cell lines. Asian J Pharm Clin Res. 2013;6(4):60-4

43. Arulmozhi K, Wilson L. In vitro antioxidant properties of Moringa oleifera and Tagetes erecta flower extracts. IJCMAS. 2015;4(10):733-40.

44. Fakurazi S, Sharifudin SA, Arulselvan P. Moringa oleifera hydroethanolic extracts effectively alleviate acetaminophen-induced hepatotoxicity in experimental rats through their antioxidant nature. Molecules. 2012;17(7):8334-50. http://dx.doi org/10.3390/molecules17078334; PMid:22781444.

45. Yadav S, Srivastava J. Analysis of antioxidant activity of various solvent extracts of leaf, flower and pod of Moringa oleifera. IJIPSR. 2014;2(12):2994-3000.

46. Siddhuraju P, Abirami A, Nagarani G, Sangeethapriya M. Antioxidant Capacity and Total Phenolic Content of Aqueous Acetone and Ethanol Extract of Edible Parts of Moringa oleifera and Sesbania grandiflora. International Journal of
Biological, Biomolecular, Agricultural, Food and Biotechnological Engineering 2014;8(9):1090-8.

47. Alhakmani F, Kumar S, Khan SA. Estimation of total phenolic content, in vitro antioxidant and anti-inflammatory activity of flowers of Moringa oleifera. APJTB. 2013;3(8):623-7. http://dx.doi.org/10.1016/S2221-1691(13)60126-4.

48. Nascimento JA, Araújo KL, Epaminondas PS, Souza AS, Magnani M, Souza AL, et al.. Ethanolic extracts of Moringa oleifera Lam. Evaluation of its potential as an antioxidant additive for fish oil. JTAC. 2013;114(2):833-8.

49. Caceres A, Saravia A, Rizzo S, Zabala L, De Leon E, Nave F. Pharmacological properties of Moringa oleifera. 2: Screening for antispasmodic, anti-inflammatory and diuretic activity. J Ethnopharmacol. 1992;36(3):233-7. http://dx.doi. org/10.1016/0378-8741(92)90049-W.

50. Ruckmani K, Kavimani S, Anandan R, Jaykar B. Effect of Moringa oleifera Lam on paracetamol-induced hepatotoxicity. Indian Journal of Pharmaceutical Sciences. 1998:60(1):33.

51. Kumar P, Singh K, Kumar A. Hepato protective studies on aerial parts of Moringa oleifera Lam. on Carbon tetrachloride induced liver cell damage in albino rats. Annals of Biological Research. 2010;1(1):27-35.

52. Johri R, Dayal V, Johri PK. Ethanolic extract of Moringa oleifera Lam. flowers provide protection against arsenic induced toxicity in albino rats. J Exp Zool India. 2011;14(2):431-4.

53. Krishnaveni J, Ananthi T. Hepatoprotective Effect of Moringa oleifera in Isoniazid Induced Rats. RJPT. 2011;4(12):1901-3

54. Akhtar $\mathrm{AH}$, Ahmad KU. Anti-ulcerogenic evaluation of the methanolic extracts of some indigenous medicinal plants of Pakistan in aspirin-ulcerated rats. J Ethnopharmacol. 1995;46(1):1-6. http://dx.doi.org/10.1016/0378-8741(94)01220-T.

55. Mahajan SG, Mehta AA. Anti-Arthritic Activity of Hydroalcoholic Extract of Flowers of Moringa oleifera Lam. in Wistar Rats. J Herbs Spices Med Plants. 2009:15(2):149-63. http://dx.doi.org/10.1080/10496470903139363.

56. Patel C, Rangrez A, Parikh P. The anti-osteoporotic effect of Moringa oliefera on osteoblastic cells: SaOS 2 .IOSR-JPBS. 2013:5(2):10-7. http://dx.doi. org/10.9790/1684-0951014 http://dx.doi.org/10.9790/3008-0521017.

57. Patel C, Ayaz RM, Parikh P. Studies on the Osteoprotective and Antidiabetic Activities of Moringa oleifera Plant Extract. IOSR PHR. 2015;5(5):19-22.

58. Adejumo OE, Kolapo AL, Folarin AO. Moringa oleifera Lam. (Moringaceae) grown in Nigeria: In vitro anti sickling activity on deoxygenated erythrocyte cells J Pharm Bioall Sci. 2012;4(2):118. http://dx.doi.org/10.4103/0975-7406.94812 PMid:22557922 PMCid:PMC3341715

59. Mukherjee K, Nandi R, Saha D, Saha B. Surfactant-assisted enhancement of bioremediation rate for hexavalent chromium by water extract of Sajina (Moringa oleifera) flower. Desalin Water Treat. 2015;54(2):525-32. http://dx.doi. org/10.1080/19443994.2014.884477.

60. Arise AK, Arise RO, Sanusi MO, Esan OT, Oyeyinka SA. Effect of Moringa oleifera flower fortification on the nutritional quality and sensory properties of weaning food. Croatian Journal of Food Science and Technology. 2014;6(2):6571. http://dx.doi.org/10.17508/CJFST.2014.6.2.01.

61. Pontual EV, Carvalho BE, Bezerra RS, Coelho LC, Napoleão TH, Paiva PM Caseinolytic and milk-clotting activities from Moringa oleifera flowers Food Chemistry. 2012;135(3):1848-54. http://dx.doi.org/10.1016/j.foodchem.2012.06.087; PMid:22953932.

62. Anand K, Gengan RM, Phulukdaree A, Chuturgoon A. Agroforestry waste Moringa oleifera petals mediated green synthesis of gold nanoparticles and their anti-cancer and catalytic activity. J Ind Eng Chem. 2015;21:1105-11. http:// dx.doi.org/10.1016/j.jiec.2014.05.021.

63. Sundrarajan M, Jegatheeswaran S, Selvam S, Sanjeevi N, Balaji M. The ionic liquid assisted green synthesis of hydroxyapatite nano plates by Moringa oleifera flower extract: A biometric approach. Mater Design. 2015;88:1183-90. http:// dx.doi.org/10.1016/j.matdes.2015.09.051. 